\title{
Association of KCNJ11 rs5219 gene polymorphism with type 2 diabetes mellitus in a population of Syria: a case-control study
}

\author{
Osama Makhzoom ${ }^{1 *}$ D, Younes Kabalan ${ }^{2}$ and Faizeh AL-Quobaili ${ }^{1}$
}

\begin{abstract}
Background: Type 2 diabetes mellitus is believed to be a polygenic disorder that develops as a result of a complex interaction between multiple genes and environmental factors. KCNJ11 gene encodes a Kir6.2 protein which forms the inner section of the potassium channels in pancreatic beta cells. Several studies found that KCNJ11 polymorphism increases T2DM risk. Our study aimed to investigate the association between rs5219 polymorphism of the KCNJ11 gene and T2DM in Syrian patients.
\end{abstract}

Methods: This case-control study involved 75 T2DM patients and 63 healthy controls. The KCNJ11 rs5219 polymorphism was genotyped by Restriction Fragment Length Polymorphism (RFLP).

Results: The frequency of the risk allele $\mathrm{K}$ was similar between the two groups (38.7\% vs. 38.1\%, $P=0.132)$. The frequency of the KK genotype was higher among the patients' group (16\% vs. 4.8\%), and the frequency of the EK genotype was higher among the control group (45.3\% vs. 66.6\%); however, the differences were statistically insignificant. The KK genotype was significantly associated with T2DM in the recessive model with an OR of $3.81(95 \% \mathrm{Cl} 1.024-14.17$, $P=0.035)$.

Conclusions: This study showed that rs5219 polymorphism of the KCNJ11 gene is an important risk factor for type 2 diabetes mellitus in a sample of the Syrian population.

Keywords: KCNJ11, Polymorphism, rs5219, RFLP, Potassium channels, Beta cells, Type 2 diabetes, Syria

\section{Background}

The global rate of diabetes has increased significantly over the past two decades, reaching 451 million in 2017, and it is expected to reach more than 693 million in 2045 [1]. The Center for Disease Control and Prevention (CDC) in the United States of America had published that about 30.3 million people, equivalent to $9.4 \%$ of the US population, were diabetic as of 2015 [2]. In Syria, the proportion of people with diabetes was $11.9 \%$ in 2016 based on a World Health Organization report [3].

T2DM is believed to be a polygenic disorder that develops as a result of a complex interaction between

\footnotetext{
* Correspondence: dr.makhzoom@gmail.com

${ }^{1}$ Clinical Biochemistry Department, Faculty of Pharmacy, Damascus University, Damascus, Syria

Full list of author information is available at the end of the article
}

multiple genes and environmental factors. This genetic component is more likely to be due to single-nucleotide polymorphisms (SNPs) [4]. Studies have identified several genes that may be associated with T2DM; among these, the Potassium Voltage-Gated Channel Subfamily J Member 11 gene, which has received significant attention as an important candidate gene for T2DM risk, due to its function in the regulation of glucose-induced insulin secretion [5]. The KCNJ11 gene is located at 11p15.1 and contains one exon that encodes Kir6.2 protein which forms the inner section of the adenosine triphosphate sensitive potassium ion channel (KATP) in pancreatic beta cells, and plays a crucial role in insulin secretion. Several SNPs of the KCNJ11 gene have been detected, among them, rs5219, which has been receiving more attention for its association with diabetes. KCNJ11

(c) The Author(s). 2019 Open Access This article is distributed under the terms of the Creative Commons Attribution 4.0 International License (http://creativecommons.org/licenses/by/4.0/, which permits unrestricted use, distribution, and reproduction in any medium, provided you give appropriate credit to the original author(s) and the source, provide a link to the Creative Commons license, and indicate if changes were made. The Creative Commons Public Domain Dedication waiver (http://creativecommons.org/publicdomain/zero/1.0/) applies to the data made available in this article, unless otherwise stated. 
rs5219 polymorphism is caused by a switch of guanine to adenine at codon 23 , resulting in a glutamic acid to lysine amino acid substitution and thereby a critical inhibition of glucose-induced insulin secretion. This alteration reduces potassium channels' sensitivity to ATP molecules, resulting in over-activity of the channel and subsequent inhibiting insulin secretion [6-8].

Several studies have observed an association between KCNJ11 rs5219 polymorphism and T2DM risk. However, there are inconsistent results in previous studies in Asian populations [7-9], and there is no study has been carried out in a population of Syria, so we found it is important to investigate the association between KCNJ11 rs5219 polymorphism and T2DM in the Syrian population.

\section{Methods}

\section{Study population}

The study is a case-control study. It included 138 participants of Syrian Arab ethnicity, aged above 40 years. The case group included 75 T2DM patients (38 men and 37 women; median age 47.4 years), who were diagnosed according to the American Diabetes Association criteria (a fasting plasma glucose more than $126 \mathrm{mg} / \mathrm{dl}$, or a plasma glucose more than $200 \mathrm{mg} / \mathrm{dl}$ after 2 -h of oral glucose $(1.75 \mathrm{~g} / \mathrm{kg})$ or $\mathrm{HbA} 1 \mathrm{c} \geq 6.5 \%)$ [10]. The control group included 63 individuals (32 men and 31 women; median age 47.9 years), who were apparently healthy with a fasting plasma glucose less than $100 \mathrm{mg} / \mathrm{dl}$, HbA1c $<5.7 \%$, and a negative family history of T2DM. The exclusion criteria included the patients with type I diabetes, pancreatitis, chronic gastrointestinal diseases associated with poor absorption, cancers, liver failure, or other clinical conditions likely to cause hyperglycemia such as; infections, thyroid disease, surgeries, medications which affect glucose levels. This case-control study was approved by the ethics committee of the University of Damascus, and written informed consent was obtained by all participants. The study was carried out at the laboratories of the biotechnology research center at Al-Baath University in the period from November 2016 to May 2018.

\section{Sampling}

Samples of $5 \mathrm{ml}$ venous blood $(2 \mathrm{ml}$ on a dry tube and 3 $\mathrm{ml}$ divided into two EDTA tubes) were taken after fasting for about $10 \mathrm{~h}$. The dry tube was centrifuged at 1680 $\mathrm{Xg}$ for $10 \mathrm{~min}$, and the glucose level was directly measured. The first EDTA tube was used to measure the hemoglobin $\mathrm{A} 1 \mathrm{c}$, which was stored at $4{ }^{\circ} \mathrm{C}$ for $2-7$ days until the time of the assay, and the second was used to isolate the DNA and study the genetic variation.

\section{Biochemical assays}

Glucose level was assayed by an enzyme-based method (Glucose Oxidase Peroxidase) using the Biosystems kit (Spain), and HbA1c was assayed by an ion exchange resin method using the Biosystems kit (Spain).

\section{Molecular genotyping}

DNA was isolated from the whole blood using the GF-1 Blood DNA extraction kit (Vivantis, Malaysia). The concentration and purity of the isolated DNA were measured using the Biospecnano device (Shimadzue, Japan). The isolated DNA was stored at $-20^{\circ} \mathrm{C}$ for polymerase chain reaction (PCR). KCNJ11-rs5219 polymorphism was genotyped by restriction fragment length polymorphism (RFLP), and PCR reaction was performed using TECHNE TC512, Gradient Thermal Cycler (Bibby Scientific, UK). A specific area of the KCNJ11 gene was amplified (210 bp) using PCR Master Mix (2X) (Genedirex, Malaysia), and the following primers:

\section{Forward: (5 '-GACTCTGCAGTGAGGCCCTA-3')}

Reverse: (5'-ACGTTGCAGTTGCCTTTCTT-3')

The PCR was carried out under the following conditions: Initial denaturation at $95^{\circ} \mathrm{C}$ for $5 \mathrm{~min}$, followed by 35 cycles of (a) $95^{\circ} \mathrm{C}$ for $30 \mathrm{~s}$ (denaturation), (b) $60^{\circ} \mathrm{C}$ for $30 \mathrm{~s}$ (annealing), (c) $72^{\circ} \mathrm{C}$ for $30 \mathrm{~s}$ (elongation) and final elongation at $72{ }^{\circ} \mathrm{C}$ for $9 \mathrm{~min}$.

The amplified DNA fragments (210 bp) were digested using the BanII enzyme (NEB, UK) at $37^{\circ} \mathrm{C}$ for $2 \mathrm{~h}$. The reaction volume $(10 \mu \mathrm{l})$ contained $5 \mu \mathrm{l}$ of PCR product, $1 \mu \mathrm{l}$ 10X NEB buffer, $0.5 \mu \mathrm{l}$ BanII enzyme and $3.5 \mu \mathrm{lnu}$ clease free water. The digested products were separated by electrophoresis on a $2 \%$ agarose gel with ethidium bromide and visualized under a UV transilluminator.

\section{Statistical study}

The statistical program (SPSS 16) was used for statistical analysis. The chi-square test was used to determine whether the genotype distributions were in HardyWeinberg equilibrium. The frequency of the genotypes and alleles were compared between the two groups using chi-square test. The odds ratios were calculated using a logistic regression model. $P$-value $<0.05$ was considered statistically significant.

\section{Results}

The clinical and biological characteristics of the participants are summarized in (Table 1). Significant differences were observed for body mass index (BMI), fasting plasma glucose, and hemoglobin A1c. There were no statistically significant differences for sex and age.

The DNA concentration of all samples ranged from 10 to $65 \mathrm{ng} / \mu \mathrm{l}$ with an average of $35 \mathrm{ng} / \mathrm{Ml}$. index of purity ranged from (1.7 to 1.9$)$. 
Table 1 The clinical and biological characteristics of the participants

\begin{tabular}{llll}
\hline Variables & $\begin{array}{l}\text { Patients } \\
(n=75)\end{array}$ & $\begin{array}{l}\text { Controls } \\
(n=63)\end{array}$ & P-value \\
\hline Age (years) & $47.4 \pm 5.2$ & $47.9 \pm 7.1$ & 0.923 \\
Sex (male/female) & $38 / 37$ & $32 / 31$ & 0.9 \\
Body mass index $\left(\mathrm{kg} / \mathrm{m}^{2}\right)$ & $26.1 \pm 1.7$ & $23.9 \pm 2.4$ & 0.021 \\
Fasting plasma glucose $(\mathrm{mg} / \mathrm{dl})$ & $192.32 \pm 33.4$ & $91.1 \pm 11.2$ & $<0.0001$ \\
HbA1c \% & $8.6 \pm 0.9$ & $5.1 \pm 0.2$ & $<0.0001$ \\
\hline
\end{tabular}

When a PCR reaction was applied, a band of DNA was produced with a length of $210 \mathrm{bp}$, (Fig. 1).

When applying the BanII enzyme on the PCR product, different patterns were obtained:

- One band of $150 \mathrm{bp}$ for the wild type homozygote EE.

- One band of $178 \mathrm{bp}$ for the mutant homozygote KK.

- Two bands of $178 \mathrm{bp}$ and $150 \mathrm{bp}$ for heterozygote EK, (Fig. 2).

The frequency of (EE-EK-KK) genotypes for the patients' group was $(38.7-45.3 \%-16 \%)$, and for the control group (28.6-66.6\% - 4.8\%), respectively. The difference between the two groups was statistically significant, $(P$-value $=0.02)$.

Genotype frequencies for all participants were in Hardy-Weinberg equilibrium.

The frequency of $(E-K)$ alleles was $(61.3-38.7 \%)$ in the patients' group, and (61.9-38.1\%) in the control group, respectively. The difference was shown to be statistically insignificant, $(P$-value $=0.923)$.

Four models were tested to evaluate the effect of KCNJ11- rs5219 polymorphism on T2DM, and odds ratio and P-value were calculated for each model as follows:

- Homozygote model (KK vs. EE): OR: 2.483 (95\% CI 0.615-10.02, $P=0.192)$

- Heterozygote model (EK vs. EE): OR: 0.502 (95\% CI 0.239-1.055, $P=0.067)$

- Dominant model (EK + KK vs. EE): OR: 0.634 (95\% CI $0.31-1.3, P=0.213)$

- Recessive model (KK vs. EE + EK): OR: 3.81 (95\% CI 1.024-14.17, $P=0.035$ ), (Table 2).

\section{Discussion}

T2DM is one of the most prevalent non-infectious diseases worldwide and is a major healthcare problem. The genetic factors behind the T2DM are believed to be multiple and complex in nature [4]. Therefore, there is a need to investigate these genetic factors which are associated with the risk of T2DM. Since the genetic studies of T2DM in the Middle East region are limited, we have studied the association between rs5219 polymorphism of the KCNJ11 gene and T2DM in a sample of the Syrian population.

We found that the difference between the three genotypes of KCNJ11-rs5219 polymorphism (EE- EK- KK) in the two groups was statistically significant, $(P=0.02)$.

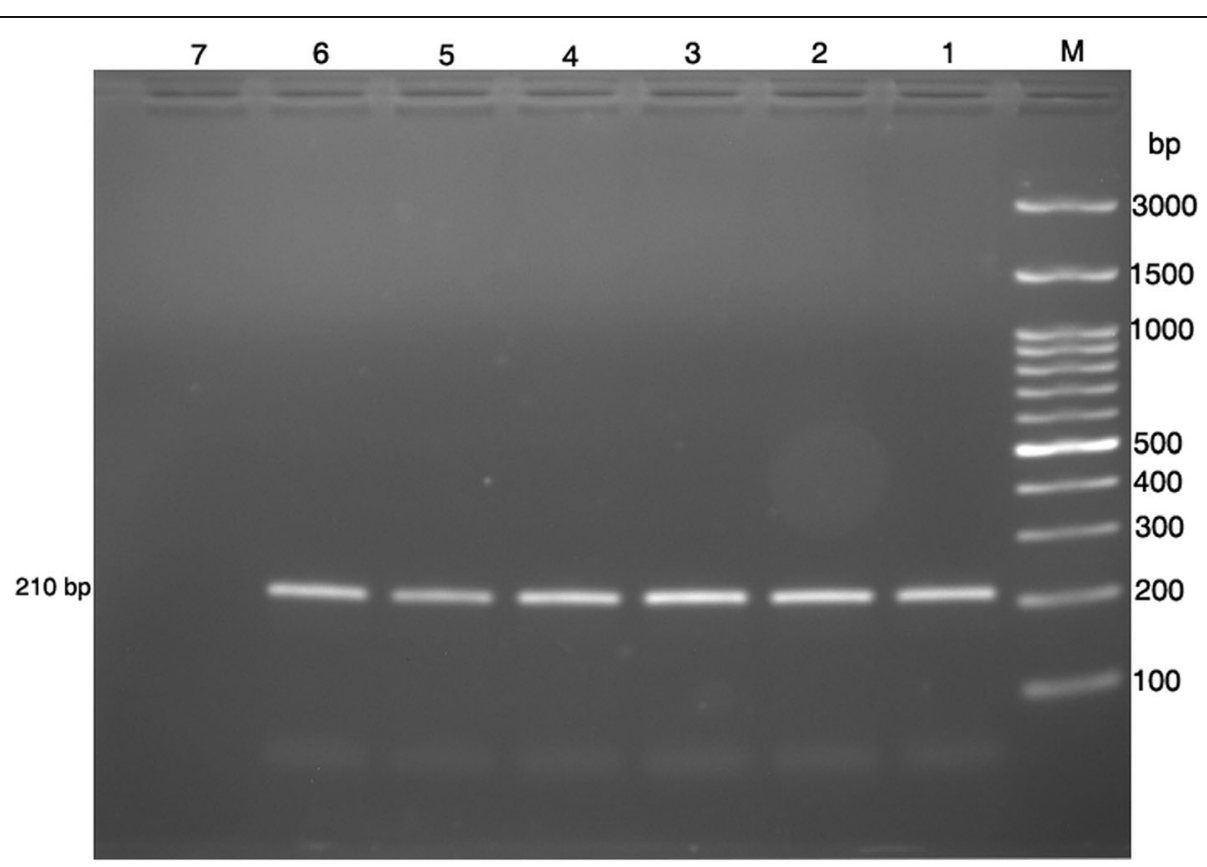

Fig. 1 The product of the PCR amplification of KCNJ11- rs5219. Samples were electrophoresed on a 2\% agarose gel. Lane M: 100 bp ladder, Lane $(1,2,3,4,5,6)$ : PCR products (210 bp), Lane 7: negative control 


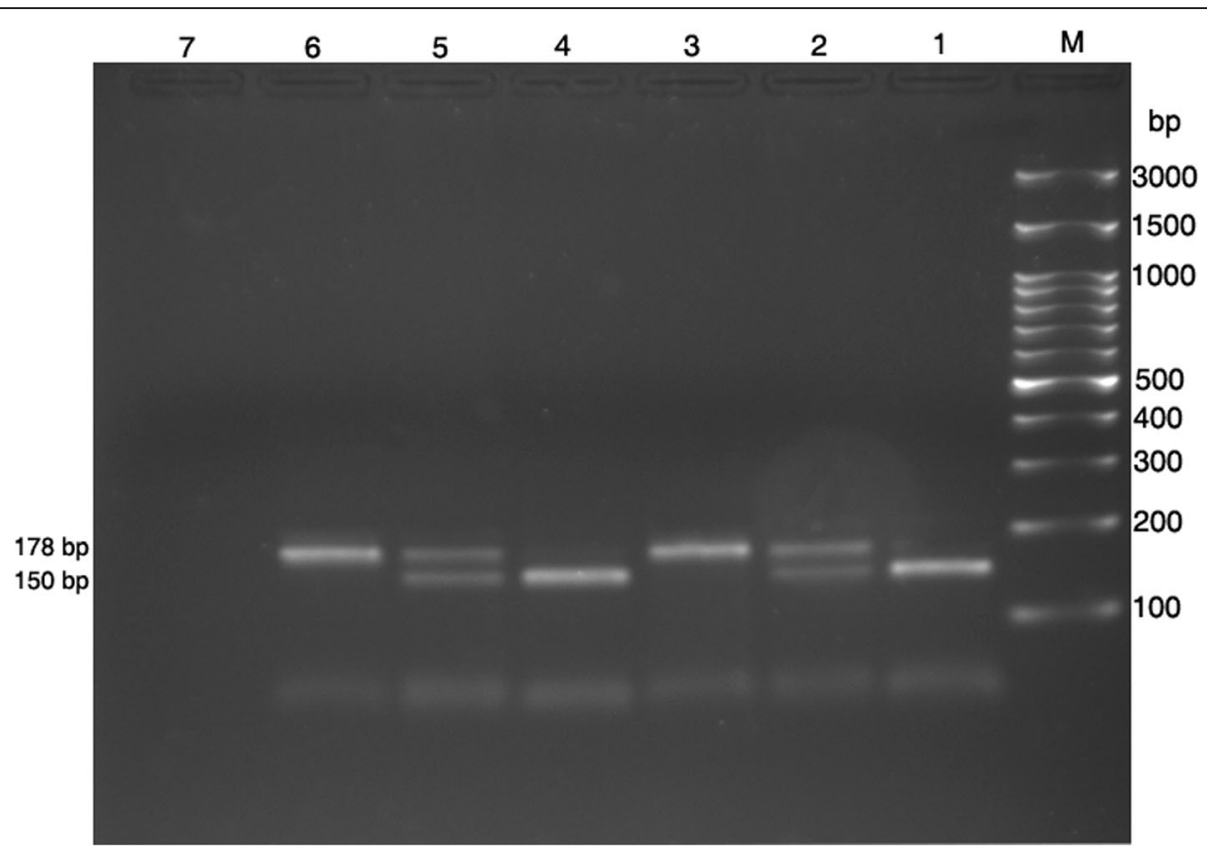

Fig. 2 Digestion products for KCNJ11- rs5219 by Banll enzyme. Samples were electrophoresed on a 2\% agarose gel. Lane M: 100 bp ladder, Lane (1,4): homozygote EE, Lane (2,5): heterozygote EK, Lane (3,6): homozygote KK

The prevalence of the $\mathrm{K}$ allele was $38.4 \%$ in our study. This is comparable to studies in Caucasian and Asian populations [9-15]. However, the K allele frequency was lower in North African populations [16-18]. This suggests a moderate difference in the risk allele $\mathrm{K}$ according to ethnicity and geographic location, (Table 3).

The frequency of the KK genotype was higher among the patients' group, whereas the frequency of the EK genotype was higher among the control group. Studies of Iranian and Russian populations found the same results $[19,20]$.
When assuming a variety of models to evaluate the association between KCNJ11 rs5219 polymorphism and T2DM risk, the recessive model (KK vs. EE + EK) was associated with the T2DM risk with an OR of 3.81 (95\% CI 1.024-14.17, $P=0.035$ ). Consequently, the KK genotype is associated with an increase in the risk of T2DM by four times.

This finding is in accord with a meta-analysis study (Wang et al., 2018) [7] which found that the recessive model is the most appropriate model for evaluating the effect of this gene variation on the risk of T2DM.

Table 2 Genetic characteristics of the T2DM patients and control groups

\begin{tabular}{|c|c|c|c|c|}
\hline Variables & Patients $(n=75)$ & Controls $(n=63)$ & OR (95\% Cl) & P-value \\
\hline \multicolumn{5}{|l|}{ Genotypes } \\
\hline$E / E$ & 29 (38.7\%) & $18(28.6 \%)$ & Reference & \\
\hline$E / K$ & $34(45.3 \%)$ & $42(66.6 \%)$ & $0.502(0.239-1.055)$ & 0.067 \\
\hline K/K & $12(16 \%)$ & $3(4.8 \%)$ & $2.483(0.615-10.02)$ & 0.192 \\
\hline \multicolumn{5}{|c|}{ Dominant model } \\
\hline$E / E$ & $29(38.7 \%)$ & $18(28.6 \%)$ & Reference & \\
\hline$E / K+K / K$ & $46(61.3 \%)$ & 45 (71.4\%) & $0.634(0.31-1.3)$ & 0.213 \\
\hline \multicolumn{5}{|c|}{ Recessive model } \\
\hline$E / E+E / K$ & $63(84 \%)$ & $60(95.2 \%)$ & Reference & \\
\hline K/K & $12(16 \%)$ & $3(4.8 \%)$ & $3.81(1.024-14.17)$ & 0.035 \\
\hline \multicolumn{5}{|l|}{ Alleles } \\
\hline$E$ & $92(61.3 \%)$ & 78 (61.9\%) & Reference & \\
\hline K & $58(38.7 \%)$ & 48 (38.1\%) & $1.024(0.629-1.667)$ & 0.923 \\
\hline
\end{tabular}


Table 3 The prevalence of the $\mathrm{K}$ allele among different populations

\begin{tabular}{|c|c|c|c|c|c|c|}
\hline Author & Year & Country & Ethnicity & Case & Control & $\mathrm{K} \%$ \\
\hline Anna L Gloyn & 2001 & UK & Caucasian & 364 & 328 & $37 \%$ \\
\hline Eva-Maria D Nielsen & 2003 & Denmark & Caucasian & 803 & 862 & $39 \%$ \\
\hline Martine Vaxillaire & 2008 & France & Caucasian & 307 & 2919 & $39 \%$ \\
\hline Yuki Sakamoto & 2007 & Japan & Asian & 909 & 893 & $36 \%$ \\
\hline Daizhan Zhou & 2009 & China & Asian & 1912 & 2041 & $40 \%$ \\
\hline Parvaneh Keshavarz & 2014 & Iran & Asian & 400 & 420 & $36 \%$ \\
\hline Khaled Lasram & 2014 & Tunisia & North African & 250 & 267 & $22 \%$ \\
\hline Isselmou Abdelhamid & 2013 & Mauretania & North African & 135 & 135 & $19 \%$ \\
\hline Houda Benrahma & 2014 & Morocco & North African & 250 & 250 & $20 \%$ \\
\hline
\end{tabular}

In a study of the Russian population, the KK genotype was associated with an increase in the risk of T2DM by two and a half times [20], and in studies of Mauritanian and German populations by two times [17-21], and in studies of Iranian and Chinese populations by one and a half times [19-22], and in a meta-analysis study (Wang et al., 2018) by one and a quarter times.

It is known that T2DM is a complex disorder caused by the interaction of multiple genetic and environmental factors, and the effects of the same genetic factor on T2DM development are not the same among people, due to their difference in the environmental elements. Many people in Syria suffer from generally poor nutritional habits and a lack of health awareness, in addition to the stress that most people have suffered as a result of the years of war. As these strong environmental elements may increase the impact of the genetic factor in the risk allele carriers, this may explain the high-risk value (four times) in our study in a sample of the Syrian population compared to other populations.

This is proven by Keshavarz et al [9], where the study of an Iranian population did not find an association between rs5219 polymorphism of the KCNJ11 gene and type 2 diabetes. However, when the results were limited to obese individuals, an association has been shown. This may confirm the increasing effect of the genetic factor in the presence of strong environmental elements.

The high-risk value may also be explained by the sample size (138 participants), which is small for such types of studies, as we noticed very big confidence intervals for odds ratio "OR 3.81 (95\% CI 1.024-14.17)". Therefore, the high-risk value may not reflect the reality accurately, and larger studies are needed.

In the control group, we have excluded individuals with positive family history of T2DM and this could reduce the chance of the controls to have the SNPs conferring risks to T2DM, including KCNJ11- rs5219 polymorphism, and subsequently may lead to bias in the selection of individuals. This may also explain the highrisk value in our study.

\section{Conclusions}

This study showed an association between rs5219 polymorphism of the KCNJ11 gene and type 2 diabetes mellitus in a sample of the Syrian population. This study supports the role of KCNJ11 rs5219 polymorphism in the pathogenesis of T2DM. Larger studies should be performed to confirm this result.

\section{Abbreviations}

CDC: Center for Disease Control and Prevention; Cl: Confidence Interval.: HbA1c: Hemoglobin A1c; KCNJ11: Potassium Voltage-Gated Channel Subfamily J Member 11; OR: Odds Ratio; T2DM: Type 2 diabetes mellitus

\section{Acknowledgements}

We thank all the patients and healthy individuals who contributed and were a part of this study. We are also grateful to the biotechnology research center staff at Al-Baath University for providing all forms of support. Also, we thank Damascus University which is responsible for this research.

\section{Consent to participate}

Informed consent was taken from all participants, as the following: The aim of this research is to investigate the association of KCNJ11 gene variation with type 2 diabetes, allowing for a better understanding of the genetic factors that influence type 2 diabetes.

This information will be confidential, and you will be informed of the study results.If you agree to participate, we will draw a blood sample of you. Also, we will collect some data related to the study about you.

If you agree, please write your name and signature.

Name and Signature.

\section{Authors' contributions}

OM conceived the idea for the research, and conducted the practical part of the study, in addition to preparing the manuscript. FQ and YK made substantial contributions to conception and design, analysis and interpretation of data. FQ and $Y K$ have been involved in revising manuscript critically for important intellectual content. All authors read and approved the final version of the manuscript.

Funding

This research received no specific grant from any funding agency.

\section{Availability of data and materials}

The datasets used and/or analyzed during the current study are available from the corresponding author on reasonable request.

Ethics approval and consent to participate

The protocol was approved by the Ethics Committee of the University of Damascus.

The members of the Ethics Committee are deans of the Faculties of Medicine, Pharmacy, Law, Sharia in Damascus University. 


\section{Consent for publication}

Not applicable.

\section{Competing interests}

The authors declare that they have no competing interests.

\section{Author details}

${ }^{1}$ Clinical Biochemistry Department, Faculty of Pharmacy, Damascus University, Damascus, Syria. ${ }^{2}$ Endocrinology Department, Faculty of Medicine, Damascus University, Damascus, Syria.

Received: 17 January 2019 Accepted: 7 June 2019

Published online: 13 June 2019

\section{References}

1. Cho NH, Shaw JE, Karuranga S, Huang Y, da Rocha Fernandes JD, Ohlrogge AW, Malanda B. IDF diabetes atlas: global estimates of diabetes prevalence for 2017 and projections for 2045. Diabetes Res Clin Pract. 2018;138:271-81.

2. National Diabetes Statistics Report, 2017 Estimates of Diabetes and Its Burden in the United States2017. https://www.cdc.gov/diabetes/pdfs/data/ statistics/national-diabetes-statistics-report.pdf. Accessed Feb 2018.

3. World Health Organization - Diabetes country profiles, Syrian Arab Republic, 2016. https://www.who.int/diabetes/country-profiles/syr_en.pdf?ua=1.

4. Kwak SH, Park KS. Recent progress in genetic and epigenetic research on type 2 diabetes. Exp Mol Med. 2016;48(3):e220.

5. Ali O. Genetics of type 2 diabetes. World J Diabetes. 2013:4(4):114-23.

6. Haghvirdizadeh P, Mohamed Z, Abdullah NA, Haghvirdizadeh P, Haerian MS, Haerian BS. KCNJ11: genetic polymorphisms and risk of diabetes mellitus. J Diabetes Res. 2015;2015:908152.

7. Wang DD, Chen $X$, Yang Y, Liu CX. Association of $\mathrm{K}_{\mathrm{ir}} 6.2$ gene rs5219 variation with type 2 diabetes: a meta-analysis of 21,464 individuals. Prim Care Diabetes. 2018;12(4):345-53.

8. Schwanstecher C, Meyer U, Schwanstecher M. KIR6.2 polymorphism predisposes to type 2 diabetes by inducing over-activity of pancreatic b-cell ATP-sensitive $K$ channels. Diabetes. 2002;51:875-9.

9. Keshavarz P, Habibipour R, Ghasemi M, Kazemnezhad E, Alizadeh M, Omami MH. Lack of genetic susceptibility of KCNJ11 E23K polymorphism with risk of type 2 diabetes in an Iranian population. Endocr Res. 2014;39(3):120-5.

10. 2. Classification and Diagnosis of Diabetes: Standards of Medical Care in Diabetes-2018. Diabetes Care. 2018;41(Suppl 1):S13-S27.

11. Gloyn AL, Hashim Y, Ashcroft SJ, Ashfield R, Wiltshire S, Turner RC. Association studies of variants in promoter and coding regions of beta-cell ATP-sensitive K-channel genes SUR1 and Kir6.2 with type 2 diabetes mellitus (UKPDS 53). Diabet Med. 2001;18:206-12.

12. Nielsen EM, Hansen L, Carstensen B, Echwald SM, Drivsholm T, Glümer C, Thorsteinsson B, Borch-Johnsen K, Hansen T, Pedersen O. The E23K variant of Kir6.2 associates with impaired post-OGTT serum insulin response and increased risk of type 2 diabetes. Diabetes. 2003;52:573-7.

13. Vaxillaire M, Veslot J, Dina C, Proença C, Cauchi S, Charpentier G, Tichet J, Fumeron F, Marre M, Meyre D, Balkau B, Froguel P. Impact of common type 2 diabetes risk polymorphisms in the DESIR prospective study. Diabetes. 2008:57:244-54.

14. Sakamoto S, Inoue H, Keshavarz P, Miyawaki K, Yamaguchi Y, Moritani M, Kunika K, Nakamura N, Yoshikawa T, Yasui N, Shiota H, Tanahashi T, Itakura M. SNPs in the KCNJ11- ABCC8 gene locus are associated with type 2 diabetes and blood pressure levels in the Japanese population. J Hum Genet. 2007:52:781-93.

15. Zhou D, Zhang D, Liu Y, Zhao T, Chen Z, Liu Z, Yu L, Zhang Z, Xu H, He L. The E23K variation in the KCNJ11 gene is associated with type 2 diabetes in Chinese and east Asian population. J Hum Genet. 2009;54(7):433-5.

16. Lasram K, Ben Halim N, Hsouna S, Kefi R, Arfa I, Ghazouani W, Jamoussi H, Benrahma H, Kharrat N, Rebai A, Ben Ammar S, Bahri S, Barakat A, Abid A, Abdelhak S. Evidence for association of the E23K variant of KCNJ11 gene with type 2 diabetes in Tunisian population: population-based study and meta-analysis. Biomed Res Int. 2014;2014:265274.

17. Abdelhamid I, Lasram K, Meiloud G, Ben Halim N, Kefi R, Samb A, Abdelhak S, Houmeida A. E23K variant in KCNJ11 gene is associated with susceptibility to type 2 diabetes in the Mauritanian population. Prim Care Diabetes. 2014;8(2): $171-5$.

18. Benrahma H, Charoute H, Lasram K, Boulouiz R, Atig RK, Fakiri M, Rouba H, Abdelhak S, Barakat A. Association analysis of IGF2BP2, KCNJ11, and CDKAL1 polymorphisms with type 2 diabetes mellitus in a Moroccan population: a case-control study and meta-analysis. Biochem Genet. 2014;52(9-10):430-42.

19. Rastegari A, Rabbani M, Sadeghi HM, Imani EF, Hasanzadeh A, Moazen F. Association of KCNJ11 (E23K) gene polymorphism with susceptibility to type 2 diabetes in Iranian patients. Adv Biomed Res. 2015;4:1.

20. Chistiakov DA, Potapov VA, Khodirev DS, Shamkhalova MS, Shestakova MV, Nosikov W. The KCNJ11 E23K and ABCC8 exon 31 variants contribute to susceptibility to type 2 diabetes, glucose intolerance and altered insulin secretion in a Russian population. Diabetes Metab Syndr Clin Res Rev. 2008; 2:185-91.

21. Fischer A, Fisher E, Möhlig M, Schulze M, Hoffmann K, Weickert MO, Schueler R, Osterhoff M, Pfeiffer AF, Boeing H, Spranger J. KCNJ11 E23K affects diabetes risk and is associated with the disposition index: results of two independent German cohorts. Diabetes Care. 2008;31(1):87-9.

22. Li YY. The KCNJ11 E23K gene polymorphism and type 2 diabetes mellitus in the Chinese Han population: a meta-analysis of 6,109 subjects. Mol Biol Rep. 2013:40:141-6.

\section{Publisher's Note}

Springer Nature remains neutral with regard to jurisdictional claims in published maps and institutional affiliations.

Ready to submit your research? Choose BMC and benefit from:

- fast, convenient online submission

- thorough peer review by experienced researchers in your field

- rapid publication on acceptance

- support for research data, including large and complex data types

- gold Open Access which fosters wider collaboration and increased citations

- maximum visibility for your research: over $100 \mathrm{M}$ website views per year

At BMC, research is always in progress.

Learn more biomedcentral.com/submissions 